\title{
CHANGE AND CONTINUITY IN INDONESIAN FOREIGN POLICY
}

\author{
Yanyan Mochamad Yani \\ Lecturer at the Department of International Relations, \\ Faculty of Social and Political Sciences, \\ Padjadjaran University \\ e-mail: yan2m@hotmail.com
}

\begin{abstract}
This article focuses on Indonesian foreign policy change and continuity and then the discussion of foreign policy at present. The analysis is carried out in six periods of Indonesia's foreign policy change and continuity, namely Soekarno's Old Order Era period (1945-1965), Soeharto's New Order Era period (1965-1998), and four Indonesian governments in the Reformation Era; Habibie period (1998-Oct1999), Abdurahman Wahid period (1999-July 2001), Megawati Soekarnoputri period (2001-October 2004), and Susilo Bambang Yudhoyono period (2004 - now). This paper concludes that since the fall of Soeharto, Indonesia's diplomacy was called upon to play a substantive role in meeting an array of challenges in the economic, political and social fields that threatened the unity, integrity, and sovereignty of the Republic.
\end{abstract}

Key words: Foreign policy, change, continuity, reform, diplomacy.

\section{PERUBAHAN DAN KONTINUITAS KEBIJAKAN LUAR NEGERI INDONESIA}

\begin{abstract}
ABSTRAK. Tulisan ini memusatkan perhatian pada perubahan dan kesinambungan dalam politik luar negeri Indonesia serta pembahasan pada pelaksanaan politik luar negeri saat ini. Analisis tulisan ini meliputi enam periode politik luar negeri Indonesia yaitu Era Orde Lama Soekarno (1945-1965), Era Orde Baru Soeharto (1965-1998), dan empat pemerintahan Indonesia di Era Reformasi; pemerintahan Habibie (1998-Okt. 1999), pemerintahan Abdurahman Wahid (1999Juli 2001), pemerintahan Megawati Soekarnoputri (2001-Okt. 2004), dan pemerintahan Susilo Bambang Yudhoyono (2004 - sekarang). Tulisan ini menyimpulkan, bahwa sejak jatuhnya Soeharto, diplomasi Indonesia telah memainkan peran yang substantif dalam menghadapi tantangan di bidang sosial, ekonomi, politik yang mengancam kesatuan, integritas, dan kedaulatan Republik Indonesia.
\end{abstract}

Kata kunci: Politik luar negeri, perubahan, kesinambungan, reformasi, diplomasi, Indonesia. 


\section{INTRODUCTION}

Indonesian foreign policy has always considered situations within a series of circles (Anwar, 1994: 150-155) in which it plays a geo-political and geo-economic role: the world at large, the Asia-Pacific region; the Indian Ocean rim region; the Southwest Pacific, East Asia and Southeast Asia or the ASEAN region. Then, of course, there is the Indonesian domestic situation. Interactions in all of these geographic circles are major factors in the shaping of Indonesian foreign policy, including and especially the Indonesian domestic situation. This paper suggests that it is the later factor that determines Indonesia's foreign policy aspirations and capability.

At the beginning of the $21^{\text {st }}$ Century the primacy of domestic context on Indonesia's foreign policy has changed as the outside world has pressed in. Specifically, it resulted from a changing and fluid situation in international affairs and Indonesia's domestic crises, for instance, the Indonesia's economic and political crises since mid-year 1997, the East Timor Referendum in 1999 as well as social, economic and political upheavals.

The nature of the problem for this case study relates to the search for an explanation of Indonesian foreign policy at the point at which influences arising in the international system cross the domestic arena and at which domestic politics is transformed into international behaviour.

Three considerations make this case study of Indonesia particularly instructive in this regard. First, Indonesian foreign policy is uniquely affected by domestic events and actors. Indonesia's foreign policy reflects the beliefs and actions of policymakers at the bureaucratic institutions who are influenced, in varying degrees and in varying ways, by the society and the international system in which they operate. This interaction results in a politics of continuity but also change in foreign policy. In this regards, foreign policy refers to the scope and collection of goals, strategies, and instruments that are selected by governmental policymakers to respond abroad to the present and future international environment.

The concept of change refers to foreign policy phenomena that experience broad alteration, ranging from more modest shifts to major foreign policy restructuring. Continuity refers to broad patterns in foreign policy that tend to persist over time, encompassing more micro and incremental changes. 'Change cannot be discerned or assessed unless it is analysed in the context of previously constant - or continuous - behaviour' (Rosenau, 1978: 372). Continuity and change 'are thus conceived to be opposite sides of the same coin' (Rosenau, 1990: 19).

Foreign policy change, in sum, tends to reflect changes that take place in the structures, beliefs, and politics of society and the state within a dynamic systemic or international context. A period of political instability and transition may produce such changes, which result from the nature and timing of events and crises in triggering change (Broesamle, 1990: 460). 
In examining the range of likely foreign policy patterns resulting from a period of transition, four outcomes are possible (Hagan, 1989: 505-541):

- Intensification: No or little change - the scope, goals, and strategy of foreign policy are reinforced.

- Refinement: Minor changes in the scope, goals, and strategy of foreign policy.

- Reform: Moderate changes in the scope, goals, and strategy of foreign policy

- Restructuring: Major changes in the scope, goals, and strategy of foreign policy.

To reiterate, politics during a time of instability and transition may produce a range of foreign policy outcomes from little change at all (where foreign policy continuity prevails) to foreign policy restructuring (most visible and intense). The concept of scope refers to the arena where a nation-state is perceived to behave, such as a regional orientation or a global orientation; goals refers to the general direction for day to day actions and policies; and strategy refers to the means of pursuing a goal.

On the basis of the generalities presented above, as a starting point, it can be eventually concluded that at the beginning of the $21^{\text {st }}$ century Indonesia has been facing new challenges and opportunities in its international relations, both bilateral and multilateral, and will react to them. Indonesia will seek to improve its foreign policy behaviour by means of both bilateral and multilateral approaches to other countries. More importantly, in accordance with the two approaches suggested above, Indonesia has developed and applied certain strategies designed to capitalise on the opportunities available and minimise the problems in its foreign relations, and will continue to do so for the sake of its national interests.

Second, in the Reformation era there have been remarkable changes and challenges in the broader Indonesian political sphere. One of the most noteworthy aspects of Indonesian foreign policy in the reformation era has been the extent to which it has been shaped by domestic factors. Specifically the political climate following the fall of Soeharto impacts on the foreign policy process in the following ways: (i) it opens up greater public scrutiny and criticism ; (ii) it increases the number and weight of foreign policy actors; (iii) domestic political and economic imperatives influence the choice of priorities and their implementation. Apart from these challenges, the implementation of Indonesian foreign policy has had to contend with a rising demand for greater transparency, a demand expressed through the views of civil society, and within the government's legislative and executive branches.

Third, the ultimate role of re-emerging Indonesia in international relations will be shaped as much by the vicissitudes of its domestic politics and economics as by the more visible changes in the country's place in the international order. In view of these developments and challenges, Indonesia has had to take a good second look at what is called as Indonesia's free and active foreign policy and to make a number of necessary adjustments. 
Indonesia is one of many interesting cases of a government undertaking to reorient its foreign policy. This study is concerned with a type of foreign policy behaviour where the Indonesian government seeks to change the pattern of its external relations. Changes usually occur both in patterns of partnerships and in the types of activity. Changes, in brief, are in both geographic and functional sectors. In this respect this study has as its genesis an interest in particular aspect of foreign policy, namely foreign policy change (East, et.al., 1978; Holsti, 1982). It focuses on a particular type of foreign policy change in terms of alterations of a nation's pattern of external relations. This study examines this important foreign policy phenomenon, a type of political behaviour that has been largely neglected in international relations theory, except in analyses of Third World states' foreign policies (Singer, 1972; Shaw and Heard, 1976).

This paper is intended to examine crises and challenges to Indonesian foreign policy before and after Soeharto's New Order. The main concerned is Indonesia's political and economic crises resulting from the Asian financial crisis since mid-year 1997 and therefore their impacts on Indonesia's foreign policy post-Soeharto will be examined. It is assumed that Indonesia's foreign policy begins in the domestic domain and that Indonesia's foreign policy always has been and still is subject to domestic political developments and priorities.

\section{METHOD}

The study describes Indonesia's pattern of foreign relations from Soekarno government up to the current Indonesian government, Susilo Bambang Yudhoyono government. It applied a comparative method to indicate the degree of change through the actions taken by the Indonesian governments, specific agencies, and political elites to establish new patterns.

\section{RESULT AND DISCUSSION}

In the introduction section it is suggested that Indonesia's foreign policy begins within the domestic domain. Indonesia's foreign policy has always been subjected to domestic political developments and priorities. In other words, Indonesia's foreign policy is a reflection, extension, and continuation of domestic policy.

It reveals that from Indonesia's independence in 1945 up to the current time, domestic imperatives such as commitment to economic development and need to stabilise domestic politics, which were influenced by nationalism emerge as the dominant factors in accounting for change and continuity in Indonesia's foreign policy-making.

Nationalism not only forged a united Indonesian nation out of the multitude of ethnic groups but, equally important, it remains a major guiding force in the country's relations with the outside world. Indonesia's nationalism does not manifest itself in a desire to assert the country's superiority over all others. Instead, its nationalism tends to be inward-looking in nature, primarily designed to 
Change and Continuity in Indonesian Foreign Policy (Yanyan Mochamad Yani)

build a sense of oneness among the peoples and to maximise the country's independence in the international arena.

Table 1. Indonesian Foreign Policy: Change and Continuity

\begin{tabular}{|c|c|c|c|c|c|}
\hline \multirow[b]{2}{*}{ Governments } & \multicolumn{3}{|c|}{ The Primacy of Domestic Context } & \multirow[b]{2}{*}{$\begin{array}{l}\text { Performance of } \\
\text { Foreign Policy }\end{array}$} & \multirow[b]{2}{*}{$\begin{array}{l}\text { External } \\
\text { Orientation }\end{array}$} \\
\hline & Nationalism & $\begin{array}{c}\text { Economic } \\
\text { Development }\end{array}$ & $\begin{array}{c}\text { Domestic } \\
\text { Politics }\end{array}$ & & \\
\hline $\begin{array}{c}\text { SOEKARNO } \\
(1945-1965)\end{array}$ & $\begin{array}{c}\text { struggle for } \\
\text { independence }\end{array}$ & $\begin{array}{l}\text { - socialism } \\
\text { - self-sufficient }\end{array}$ & $\begin{array}{l}\text {-multi-party system } \\
\text { - liberal democracy } \\
6 \text { democracy }\end{array}$ & $\begin{array}{l}\text {-free \& active } \\
\text { based on East- } \\
\text { West conflict } \\
\text { - non-alignment } \\
\text {-as a political } \\
\text { weapon of } \\
\text { competing } \\
\text { political forces }\end{array}$ & $\begin{array}{l}\text { High Profile } \\
\text { but erratic }\end{array}$ \\
\hline $\begin{array}{c}\text { SOEHARTO } \\
(1965-M a y \\
1998)\end{array}$ & $\begin{array}{l}\text { national } \\
\text { building } \\
\text { (internal } \\
\text { stability and } \\
\text { economic } \\
\text { development) }\end{array}$ & $\begin{array}{l}\text {-capitalism } \\
(1967-1997) \\
\text {-regional crisis } \\
(1997-1998)\end{array}$ & $\begin{array}{l}\text {-single majority } \\
\text { party system } \\
\text {-pancasila } \\
\text { democracy } \\
\text {-dual function of } \\
\text { ABRI } \\
\text {-centralised } \\
\text { authoritarian rule } \\
\text {-human right abuses }\end{array}$ & $\begin{array}{l}\text {-free } \& \text { active } \\
\text { based on } \\
\text { economic-oriented } \\
\text { - pseudo-non- } \\
\text { alignment } \\
\text {-advancing } \\
\text { domestic political } \\
\text { interests of the } \\
\text { ruling regime }\end{array}$ & $\begin{array}{l}\text { (1965- } \\
\text { 1980s) Low } \\
\text { Profile and } \\
\text { consistent } \\
\\
\text { (mid 1980s- } \\
\text { 1998) High } \\
\text { Profile but } \\
\text { erratic }\end{array}$ \\
\hline $\begin{array}{c}\text { HABIBIE } \\
(1998-\text { Oct } \\
1999)\end{array}$ & $\begin{array}{l}\text {-disintegration } \\
\text {-East Timor's } \\
\text { exit }\end{array}$ & $\begin{array}{l}\text { - a deepening } \\
\text { crisis }\end{array}$ & $\begin{array}{l}\text {-multi-party system } \\
\text {-pancasila } \\
\text { democracy } \\
\text {-declining of TNI's } \\
\text { role }\end{array}$ & $\begin{array}{l}\text { - foreign aid } \\
\text { diplomacy } \\
\text { - under pressure } \\
\text { of the } \\
\text { international } \\
\text { community }\end{array}$ & $\begin{array}{l}\text { Low Profile } \\
\text { and } \\
\text { consistent }\end{array}$ \\
\hline $\begin{array}{c}\text { ABDURAHMAN } \\
\text { WAHID (1999- } \\
\text { July 2001) }\end{array}$ & $\begin{array}{l}\text {-separatism } \\
\text {-disintegration } \\
\text {-ethic conflicts }\end{array}$ & $\begin{array}{l}\text {-a crippled } \\
\text { Indonesia }\end{array}$ & $\begin{array}{l}\text { - multi-party system } \\
\text {-transition era to } \\
\text { civic democracy }\end{array}$ & $\begin{array}{l}\text {-disorientation } \\
\text {-mismanaged } \\
\text { foreign policy }\end{array}$ & $\begin{array}{l}\text { High Profile } \\
\text { but erratic }\end{array}$ \\
\hline $\begin{array}{c}\text { MEGAWATI } \\
\text { SOEKARNOPU } \\
\text { TRI (2001-oct } \\
2004)\end{array}$ & $\begin{array}{l}\text {-separatism } \\
\text {-disintegration } \\
\text {-ethic conflicts }\end{array}$ & $\begin{array}{l}\text {-the } \\
\text { awakening } \\
\text { Indonesia }\end{array}$ & $\begin{array}{l}\text {-multi-party system } \\
\text {-democratic } \\
\text { consolidation } \\
\text {-introduction of } \\
\text { regional autonomy } \\
\text { - the emergence of } \\
\text { Islamic political } \\
\text { management forces } \\
\text { - new military role }\end{array}$ & $\begin{array}{l}\text { - free } \& \text { active } \\
\text { based on } \\
\text { economic-oriented } \\
\text {-reformation on } \\
\text { foreign policy }\end{array}$ & $\begin{array}{l}\text { Low Profile } \\
\text { and } \\
\text { consistent }\end{array}$ \\
\hline $\begin{array}{l}\text { YUDHOYONO } \\
(2004-\text { now })\end{array}$ & $\begin{array}{l}\text {-separatism } \\
\text {-disintegration } \\
\text {-ethic conflicts } \\
\text {-national } \\
\text { building }\end{array}$ & $\begin{array}{l}\text {-a confident } \\
\text { Indonesia }\end{array}$ & $\begin{array}{l}\text {-multi-party system } \\
\text {-civic democracy } \\
\text {-the implementation } \\
\text { of regional } \\
\text { autonomy } \\
\text {-competing of } \\
\text { Islamic versus } \\
\text { nationalitic pol. } \\
\text { forces } \\
\text { - the } \\
\text { implementation of } \\
\text { new military role }\end{array}$ & $\begin{array}{l}\text {-free \&active } \\
\text { based on } \\
\text { navigating in a } \\
\text { turbulence ocean } \\
\text {-constructive } \\
\text { mindset } \\
\text {-connectivity } \\
\text {-reflect true brand } \\
\text { of Indonesian } \\
\text { nationalism }\end{array}$ & $\begin{array}{l}\text { High Profile } \\
\text { and } \\
\text { consistent }\end{array}$ \\
\hline
\end{tabular}


Table 2. Periods of Indonesia's Foreign Policy

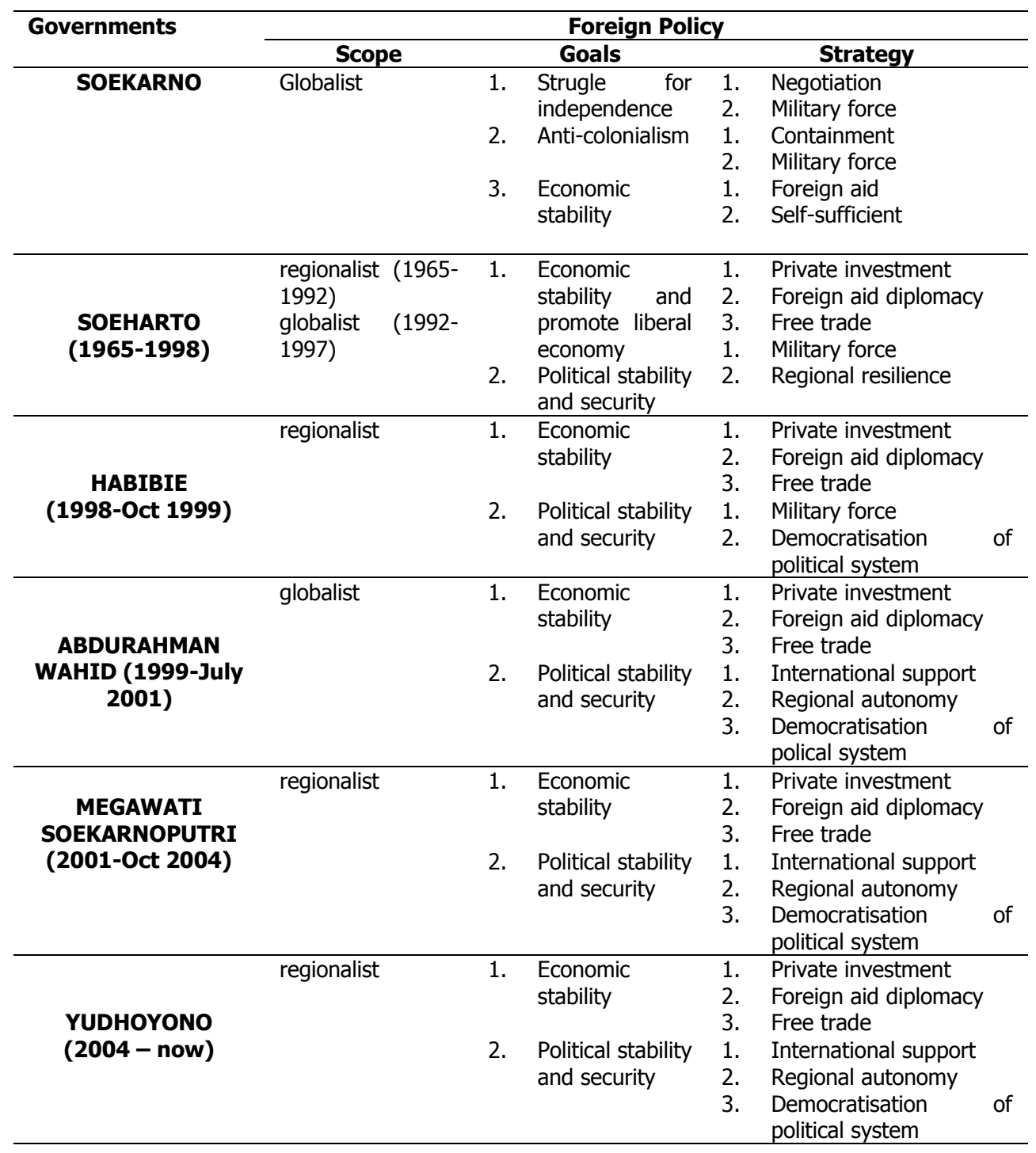

In order to underline some of the findings arising from the main body of this study, it may be useful to focus on the composite picture of change and continuity of Indonesia's foreign policy since its independence in 1945 up to the Reformation Era as shown in the Table 1 and Table 2.

As summarised in Table 1 and Table 2, Soekarno became the first President of Indonesia and committed the country to a free and active foreign policy. 
Indonesia's approach to foreign policy has been influenced heavily by the country's experiences in securing its independence from the Netherlands in an armed struggle and then needing

to maintain that independence in a world of superpower competition. Foreign policy under Soekarno (1949-1966) was radical, characterised by Soekarno's selfstyled role as revolutionary leader of the developing countries.

The new Indonesian Republic committed itself in 1948 to pursuing a 'free and active' foreign policy. Indonesia's early foreign policy concentrated on opposition to colonialism and to securing an international position apart from the prevailing Cold War competition between the United States and the Soviet Union. The hosting of the Bandung conference of non-aligned countries in 1955 and support for the NonAligned Movement after its inauguration in 1961 was a major reflection of these priorities. From the late 1950s, Indonesia's foreign policy in the era of the Soekarno government's 'guided democracy' became much more assertive, with anti-colonial rhetoric increasing and an attempt made to oppose the development of the Federation of Malaysia from 1963. The period of 'Confrontation' of Malaysia raised tensions both among Indonesia's immediate neighbours and other countries in and near Southeast Asia, including Australia which deployed combat forces to support Malaysia.

In addition, any understanding of the Old Order foreign policy should recognise that its place in domestic politics was both similar yet different to the New Order era. It is similar in the sense that foreign policy continues to reflect various impulses in domestic politics and served domestic requirements. But it is different in the sense that under the Old Order government competing political forces sought to discredit opponents by using foreign policy issues, such as in the period of guided democracy when Indonesia's foreign policy direction under Soekarno was influenced by the delicate balance of political forces within Indonesia.

Soekarno was caught between the contending forces of the army and the Communists (Partai Komunis Indonesia, PKI). Soekarno saw foreign policy as a way of diverting attention from pressing domestic issues in the interests of promoting national unity. During the early 1960s, Indonesia's foreign policy became increasingly radical, perhaps suggesting that the political balance was shifting toward the left. Soekarno proclaimed Indonesia to be a leader of the New Emerging Forces (NEFOS) in opposition to the Old Established Forces (OLDEFOS), and Indonesia was linked to other radical Asian states in a Jakarta - Phnom Penh Hanoi - Beijing - Pyongyang axis. This was also the time that Soekarno launched konfrontasi against Malaysia. Soekarno's foreign policy had taken Indonesia on a left-ward course with his Jakarta-Phnom Penh-Hanoi-Pyongyang-Pekong Axis which had put Indonesia at odd with the whole Western world, culminating in Indonesia's exit from the United Nations. Meanwhile in the New Order era foreign policy was no longer permitted to be used as a political weapon. 


\section{Soeharto Period}

After Soekarno's overthrow and replacement by the 'New Order' government of President Soeharto a new era of Indonesian foreign policy began. Indonesia now concentrated on economic reconstruction, supported by international assistance coordinated through the Inter-Government Group on Indonesia (IGGI), established in 1967. Indonesia now generally eschewed assertive stances in foreign relations (with the major exception of its strenuous efforts to secure the end of Dutch rule in West Irian) and emphasised the rebuilding of regional cooperation and regional resilience through the Association of Southeast Asian Nations (ASEAN - inaugurated in August 1967). These steps indicated the regionalist era in Indonesia's foreign policy had begun.

From the mid 1980s, a third phase in Indonesian foreign policy has been emerging. Indonesia has retained its close focus on ASEAN relationships but has also moved to adopt a wider foreign policy role. Indonesia's record of sustained economic growth has given its leaders increased confidence about their country's international standing. Indonesian economic policy from the mid 1980s also began to increase efforts towards deregulation and encouraging a more open involvement in the wider regional and international economy, for instance, Indonesia thus became increasingly interested in regional economic cooperation and joined the Asia Pacific Economic Cooperation (APEC) in 1989.

With the end of the Cold War in 1989 Indonesia had an opportunity to launch a higher profile foreign policy, and reaffirm its commitment to the free and active doctrine. The new international focus on economic development and cooperation, replacing the earlier focus on ideological conflicts, gave Indonesia a new opportunity to pursue the free and active foreign policy principle.

Despite having major diplomatic problems in its dealing with other countries, Indonesia also displayed positive foreign behaviour. For instance, Indonesia hosted the tenth summit of the Non-Aligned Movement (NAM) in Jakarta in 1992 and led the movement for the period 1992-1995. And Indonesia was the Chair of APEC for 1993-1994, and hosted the APEC meetings of ministers and economic leaders in Jakarta and Bogor in November 1994. To cap that, Indonesia was also elected into the United Nations Security Council as a non-permanent member from Asia for 1995-1996. This meant a widening of Indonesia's foreign policy focus from ASEAN and its Dialogue Partners to a more global orientation.

Thus, under Soeharto (1966-May 1998), the external orientation of Indonesia was high profile. Indonesian foreign policy was characterised by an emphasis on stability, with Indonesia developing a leading role in ASEAN, APEC and the NonAligned Movement but also maintaining good relations with the West. It was, however, attended with neglect of domestic development (erratic). Despite achieving good results in the implementation of its foreign policy, at home the Soeharto marred its foreign policy by human rights abuses, centralised authoritarian rule, the weakening of the non-executive branches of government, 
increased military involvement in politics and business, corruption and the violent annexation of East Timor in 1975/76.

The primary objectives of Soeharto's foreign policy during the New Order era were to mobilise international resources to assist in the country's economic rehabilitation and development, and to ensure a secure regional environment that would allow Indonesia to concentrate on its domestic agenda. Therefore the foreign policy of Soeharto's New Order was directed to achieve the twin objectives of internal stability and economic development. The New Order government fostered good relations with the Western countries, especially the USA, Europe, and Japan. These countries have played an important role in Indonesia's economic transformation by providing aid, loans, investment, market access, technology transfer, and other economic assistance.

During the New Order era Soeharto delegated most foreign policy-making to the military and smaller share to the Ministry of Foreign Affairs (MoFA). The military had overshadowed the functions of MoFA in executing foreign policymaking (Suryadinata, 1996: 45-46). This was believed to be in accordance with general trend of the military's influence over every function in public policy, governance or bureaucracy. The superiority of the military over the bureaucrat (MoFA) was obvious (Sukma, 1997: 206-249), for example, in the questions of East Timor, the problem of external threat and - to some extent - Indonesian position toward ASEAN (Anwar, 1994). Equally important were Indonesia's relations with other neighbours, especially Australia, and some major powers such as the United States of America, Japan, and the European Countries. Indeed in a country where politics has been dominated by considerations of security and stability since the start of the New Order, it is not surprising that the military should play a substantial role in foreign policy.

However, when Indonesia's economy declined sharply in 1997 this rapidly eroded the legitimacy of the New Order regime. This was not surprising, since economic growth through political obedience was the great promise of Indonesian autocracy. On the other, an unprecedented increase in foreign debt forced Indonesia to go to the IMF for international assistance. The stage was set for a primacy of economic over political reform. National salvation and rehabilitation became the central need of Indonesia.

In this respect, the end of the Soeharto New Order era provided Soeharto's successors with new opportunities and constraints in the conduct of Indonesia's foreign policy. In the post-Soeharto New Order era the changes in the domestic scene resulted in a more diverse and pluralistic domestic environment, for example, there is a trend to an open democratic political system. Under these political conditions, domestic and foreign policies became highly transparent. Due to these unstable transitional domestic political conditions, the performance of Indonesia's foreign policy fluctuated. 


\section{Habibie Period}

In the transitional administration of B.J. Habibie it seemed that Indonesia's foreign policy was the second in importance to domestic concerns. Domestic problems clearly continued to dominant, particularly as the Habibie government faced the severe challenges of overcoming the economic crisis, managing political transition and restoring public security.

In addition this Indonesian transition government was also under pressures from international community to move Indonesia toward comprehensive and total economic and political reforms. Under these circumstances it seemed that rational domestic concerns were bound to dictate the direction of foreign policy. In this respect in order to secure international assistance for Indonesian economic recovery and international support for Indonesian democratisation programs the Habibie administration continued to maintain good relations with the International Monetary Fund (IMF), and the West in general. It could be stated that in the Habibie period the external orientation of Indonesia was low profile and consistent to domestic development.

\section{Abdurahman Wahid Period}

Moreover during the period of the Abdurahman Wahid government, a transition era to civic democracy, Indonesia was dominated by a number of domestic critical challenges, including the threat of territorial disintegration, mass violence in different parts of the country and the problems of law and order in general, the continuing economic crisis as well as the lack of national capacity to consolidate democracy and to achieve good governance. This difficult atmosphere for Indonesia was worsened by the vacillation of Indonesia's foreign policy during the period of Abdurahman Wahid government which resulted from mismanaged foreign policy.

In the Abdurahman Wahid period the external orientation of Indonesia was high profile but erratic (neglect of domestic development). Despite the extensive overseas trips covering 90 countries during President Abdurahman Wahid's 21 months tenure, there was no blueprint which clearly outlined the primary objectives of Indonesian foreign policy or the countries and organisations which were seen as of vital importance to Indonesia for promoting its primary economic and political needs, particularly when it had limited resources. Throughout that time President Wahid's foreign policy lacked coherence and a clear focus.

Thus, under two successive presidents, Habibie and Abdurrahman Wahid, Indonesia was unable to regain international respect. Consequently, among the economies devastated by the Asian financial crisis (World Bank's research publications, 1993, 1998, and 2000) of 1997-1998, Indonesia has suffered the full brunt of the social, economic and political impact of that crisis, and has been sluggish in recovering from that debacle. In this regard Indonesia has been forced to keep a low profile in the international community, as the country's credibility in the international fora has deteriorated. However, when Megawati Soekarnoputri 
assumed the country's presidency in July 2001, traces of respect and credibility began to trickle back.

\section{Megawati Soekarnoputri Period}

Indonesia, under the Megawati government, tried to regain its international stature by using foreign policy to address many domestic problems, calling the initiatives intermestic policy (the intermingling of international and domestic politics). Domestic issues, particularly economic recovery and maintenance of Indonesia's national unity, were priorities for President Megawati's administration. Indonesia was still saddled with multi-dimensional crises, but at the same time was making the transition to a more fully democratic and reformed system. International confidence in the government's ability to resolve the country's multifaceted problems had slowly increased.

In the period of the Megawati government Indonesia was in the process of reforming the national political system, Indonesian leaders chose a rather drastic form of decentralisation, from a highly centralised government to a system devolving political power to over 400 districts. They took bold steps when the People's Consultative Assembly endorsed several amendments to the 1945 Constitution: the adoption of a system of direct popular election of the President and Vice President; the adoption of a bicameral system of legislature; and the abolition by 2004 of the 38 appointed seats reserved for the military in Parliament. These decisions reflected the sensitivity of public officials, particularly legislators, to trends in public opinion.

The Megawati government had a strong commitment to win back international confidence. Indonesia aimed to achieve a strong foreign policy and diplomacy; develop foreign economic cooperation; and engage in bilateral, regional and global/multilateral cooperation. To reach these goals, Indonesia laid down the following objectives: restored Indonesia's international image; boost the economy and public welfare; strengthened national unity, stability and integrity, and preserved the nation's sovereignty; developed bilateral relations, particularly with countries that could support Indonesia's trade and investment and economic recovery; and promoted international cooperation that helped Indonesia build and maintain world peace.

In addition considering that the solution to many of its domestic problems and the success of its national development efforts depended to a large extent on the existence of a conducive international environment, and in view of what it could contribute to the improvement of the state of affairs on the regional and global scene, in the period of the Megawati government Indonesia consciously categorised its priorities in the implementation of foreign policy. Indonesia enhanced its objectives first within bilateral, then the sub-regional, then regional, and finally international organisational and functional relations. A significant change in Indonesia's foreign policy direction was anticipated under Megawati's administration. In this respect, Indonesia's foreign policy management was 
reformed. Indonesia reviewed, reoriented, and restructured its foreign policy to cope with the needs of the "new Indonesia" in the $21^{\text {st }}$ century.

\section{Indonesia under the Yudhoyono Government (Oct 2004 - now)}

In the era of Susilo Bambang Yudhoyono (SBY) administration Indonesia is still struggling in a period of democratic rivalry among its political centres/power, which theoretically could end with the return to the authoritarianism or moving towards the democratic installation (Casper and Taylor, 1996). Indonesia is in the throes of a giant transition from a centralistic, authoritarian government to a more democratic and decentralised administration.

The shift is partly caused by the political change started in 1998, following the resignation of Soeharto from the presidency. Since then, the Indonesian authoritarian system has been, to some extent, replaced with a more democratic system, and the Indonesian government could assert the supremacy of civil over the military. New political parties and interest groups have emerged. Civil society, academia and the media can be depended on to support the reform process.

The present Indonesian leadership recognises the many challenges facing the country not only in the economical, but in political, social, cultural and foreign policy fields as well. It is likely that foreign policy making in the post- New Order era becomes more diffused than before. This happens also because of stronger demands from the public to have a greater voice in decision-making generally, including in foreign affairs.

In Yudhoyono's first foreign policy speech before the Indonesian Council on World Affairs (ICWA), 20 May 2005, Yudhoyono stated that Indonesia had safely passed the two reefs. He used the metaphor navigating a turbulence ocean to describe the challenge faced by Indonesian foreign policy today. Yudhoyono outlined an interpretation to the meaning of independent and active foreign policy of Indonesia for the Cabinet of what might properly be called the first rough sketch of the President's grand foreign policy design for the coming five-years period.

First, Yudhoyono added the necessity of a constructive approach in the conduct of independent and active foreign policy. Indonesia's independence and activism must be combined with a constructive mindset. It denotes an ability to turn adversary into friend, and to turn friend into partner. Constructivism helps Indonesia to use its independence and activism to be a peace-maker, confidence builder, problem solver, and bridge builder.

Second, independent and active means that Indonesia will not enter into military alliances. Indonesia has never engaged in a military pact with a foreign country, and Indonesia will continue its policy of not allowing any foreign military bases on Indonesian territory.

Third, an independent and active foreign policy is all about connectivity. It calls Indonesia to find ways to plug into the globalised world. In other words it compels Indonesia to have an active and healthy engagement with its neighbours, 
with the major powers, and emerging powers, with the regions of the world, and with international institutions and a whole range of non-state actors.

Fourth, independent and active foreign policy should project Indonesia's international identity. Indonesia is the fourth most populous nation in the world, the world's largest Muslim population, and the world's third largest democracy. Indonesia is also a country where democracy, Islam, and modernity go hand-inhand.

Fifth, independent and active foreign policy should reflect Indonesia's brand of nationalism that is open, confident, moderate, tolerant, and outward looking. This brand of nationalism must be at the root of Indonesia's internationalism. This way, Indonesia's independent and active policy becomes relevant both to Indonesia's national interests and to the international community.

This Yudhoyono's speech provided a clear and coherent foreign policy of Indonesia which should be implemented into priorities and agendas to be a guidance for every Indonesian diplomat and widely known by Indonesian society. This especially concern with the fact that the foreign policy making in the Reformation era of Indonesia has changed.

In terms of foreign policy formation and decision-making this study reveals that in the post-New Order era the number and weight of foreign policy actors increased. The centre of decision-making in Indonesia rests with the president as mandated to the President by the People's Consultative Assembly (MPR), which is the highest body representing the people. It means that in spite of the existence of a wide range of institutions interested in foreign policy issues, the president remains at the centre of decision-making in the field. The question is whether this process will continue into the future. In the Reformation era the president does not automatically inherit a strong decision-making position as during the New Order era. A stronger role for cabinet ministers cannot be ruled out in the future, for instance, a mechanism for coordination between the economic ministers and the foreign ministers, which in the New Order era rests solely with the president, need to be developed.

Decision-making in the field of foreign affairs also rests with the president with the advice of the foreign minister, who is responsible for the implementation of such policy. In addition to the foreign minister, the president receives information and other inputs to policy-making from the commander in chief of the armed forces, especially in areas directly affecting the country's security. The role and involvement of the armed forces in the formation of foreign policy are considered consistent with its defence function. In the area of foreign economic relations, the president mainly relies on economic ministers under a coordinating minister.

The role of the House of Representatives (DPR), through its Committee I in charge of foreign and defence affairs, in the formulation and implementation of foreign policy is limited. Its function is to provide feedback and support to government policies through the institution of hearings. DPR's role in general is 
more important and effective through the institution of legislation, but this is seldom employed in the field of foreign affairs.

Other sources for feedback are the mass media and public opinion. In line with the views raised in the DPR, public opinion and mass media have been rather critical of government stances on foreign affairs.

Research and academic institutions also have a role to play in providing the intellectual input to foreign policy-making. These institutions have been in the forefront in gathering up to date information and analyses through exchanges of research works and publications and through international meetings. Apart from these challenges, the implementation of Indonesian foreign policy has had to contend with a rising demand for greater transparency, a demand expressed in the views of civil society towards not only the legislative branch, but the executive as well.

Bringing foreign policy into the domain of public debate and effective parliamentary scrutiny constitutes one of the most challenging tasks for any state seeking to become a democracy. The Reformation era governments stressed the importance for Indonesia of fostering a role for public discussion and parliamentary scrutiny that would secure a balance between professional executive management of foreign policy and democratic oversight.

Public participation in the process of decision-making in Indonesia has increased greatly since the fall of Soeharto in 1998, public awareness of the right to demand accountability from government seems to have spread, including in the field of Indonesia's foreign relations. There are growing pressures from among the public and the parliament, the mass media, and academic circles for Indonesia to take a more active, assertive, and higher profile stance in the implementation of its foreign policy.

At least there are three main groups of Indonesian Domestic Actors in the Reformation Era who involve in the Indonesia's foreign policy-making. They are the politico bureaucrats (the President, Department of Foreign Affairs, Department of Defence/the Army, the Economic Ministries, the National Parliament, Local Governments, Local Parliaments, and the Technocrats/Bappenas), the business actors (the Indonesian Chamber of Trade and Commerce/Kadin, Local Business Community), and other domestic actors (the Ruling Party, the other Political Parties, the Press, Think Thank Institutions, Academia, Islamic Organisations, Labour Unions, and Non-Governmental Organisations/NGOs). In the Reformation era the involvement these Indonesian domestic actors in the Indonesia's foreign relations (bilateral relations, regional multilateral relations, and global multilateral relations) is very significant.

In addition, Indonesia considers that a major pillar of its foreign policy is still the Association of Southeast Asian Nations (ASEAN). Just beyond that region Indonesia likewise gives importance to promoting relations with its southern and eastern neighbours, prompting Indonesia to be engaged with Australia, East Timor, the Pacific Islands Forum (PIF), the Southwest Pacific Dialogue. In the 
opposite direction is the ASEAN + 3 (the three being Japan, China and South Korea) initiative. Beyond that, Indonesia puts a premium on its relations with the United States and the European Union, both of which are major economic partners of Indonesia. At the same time, Indonesia also puts new energy into its foreign relations with Russia and China, countries with potential to help Indonesia enhance its national interests in the $21^{\text {st }}$ century.

In compliance with the 1945 Constitution Indonesia also gives importance to working with like-minded developing countries. That is why Indonesia is still deeply involved with the Non-aligned Movement (NAM), the Organisation of the Islamic Conference (OIC). Also at the global level, Indonesia hopes to strengthen multilateralism through World Trade Organisation (WTO) and the United Nations (UN).

\section{CONCLUSION}

Indonesia sought to change the pattern of its external relations. The changes usually occurred both in pattern of partnerships and in the type of activity. The changes, in brief, were in both geographic and functional sectors. Indonesia has sought to create new or essentially changed patterns of relations in both sectors. This can be seen in Indonesia's foreign relations with other countries both in terms of bilateral and multilateral relations.

This paper reveals that since the fall of Soeharto, Indonesia's foreign policy has been enduring successive crises so as to avoid becoming a failed state. Indonesia's diplomacy was called upon to play a substantive role in meeting an array of challenges in the economic, political and social fields that threatened the unity, integrity, and sovereignty of the Republic.

\section{REFERENCES}

Anwar, Dewi Fortuna. 1994. 'Indonesia's foreign policy after the cold war,' Southeast Asian Affairs. Singapore: ISEAS.

Anwar, Dewi Fortuna 1994. Indonesia in ASEAN: Foreign policy and regionalism. Singapore: ISEAS.

Broesamle, John H. 1990. Reform and reaction in twentieth century American politics. Westport: Greenwood Press.

Casper, Gretchen and Michelle M. Taylor. 1996. Negotiating democracy: Transitions from authoritarian rule. Pittsburg: University of Pittsburg Press.

East, Maurice A., Stephen A. Salmore, and Charles F. Herman, eds. 1978. Why nations act: Theoretical perspectives for comparative foreign policy studies. California: Sage Publications. 
Hagan, Joe D. 1989. 'Domestic political regime changes and third world voting realignments in the united nations, 1946-1984, International Organisation no.43, pp.505-541.

Holsti, K.J. 1982. Why nations realign: Foreign policy restructuring in the post-war world. London: George Allen \& Unwin.

Rosenau, James N. 1978. 'Restlessness, change, and foreign policy analysis', in James N. Rosenau, ed., In Search of Global Patterns. New York: Free Press.

Rosenau, James N. 1990. Turbulence in world politics: A theory of change and continuity. Princeton: Princeton University Press.

Shaw, Timothy M. and Kenneth A. Heard, eds. 1976. Cooperation and conflict in Southeren Africa: Papers on a regional sub-system. Washington DC: University Press of America.

Singer, Marshall R.. 1972. Weak states in a world of powers. New York: Free Press.

Sukma, Rizal. 1997. Indonesia's restoration of diplomatic relations with China: A study of foreign policy making and the functions of diplomatic ties, dissertation, United Kingdom: London School of Economics and Political Science.

Suryadinata, Leo. 1996. Indonesia's foreign policy under Soeharto: Aspiring to international leadership. Singapore: Times Academic Press.

World Bank. 1993. The east asian miracle: Economic growth and public policy.

World Bank. 1998. East asia: The road to recovery.

World Bank. 2000. East asia: Recovery and beyond. 